\title{
ULK1 wt Allele
}

National Cancer Institute

\section{Source}

National Cancer Institute. ULK1 wt Allele. NCI Thesaurus. Code C116613.

Human ULK1 wild-type allele is located in the vicinity of 12 q24.3 and is approximately 29

$\mathrm{kb}$ in length. This allele, which encodes serine/threonine-protein kinase ULK1 protein, plays a role in both serine/threonine protein phosphorylation and the modulation of autophagy. 